YEMETS A.

Institute of Food Biotechnology and Genomics, National Academy of Sciences of Ukraine, Ukraine, 04123, Kyiv, Osypovskoho str., 2a, e-mail: yemets.alla@nas.gov.ua

\title{
LACTOFERRIN AND PLANT RESISTANCE TO PHYTOPATHOGENS
}

Today, the development of world agriculture aims to increase the cultivation of vegetables as one of the main food products. In Ukraine, where climatic and soil conditions are favorable to obtain a high yield of different crops including fruits and vegetables, the area of arable land is equivalent to $30 \%$ of that of the European Union and $2.1 \%$ of the world's total arable land area. The cultivation of commercially valuable crops is usually associated with a high risk of bacterial and fungal infection. The growing demands in healthy food stimulate the development of new technologies of plant protection against phytopathogens. Under the favorable weather conditions, particularly in the months of wet spring and autumn, the development and spreading of phytopathogens can cause epiphytotics.

To combat the escape of bacterial and fungal pathogens from plant native defense strategies, new efficient approaches should be applied in agriculture for plant protection. These new methods should be safe both for human health and environment. As an alternative for breeding and pesticides, the use of plant biotechnological methods could provide complex long-lasting resistance of crop plants to bacterial, viral and fungal pathogens. The introduction of heterologous genes encoding antimicrobial peptides into plant genome is a promising strategy for protection of plants.

Tomatoes and potato are ones of the world's most important and widespread crops, and the Ukrainian products sector of these vegetables is a global export player in the Europe. But plant diseases can cause significant loss of different vegetable yield, up to $30-80 \%$. For instance, Clavibacter michiganensis subsp. michiganensis, C. michiganensis subsp. sepedonicus and Ralstonia solanacearum are the main bacterial pathogens that cause substantial economic losses worldwide by damaging tomatoes and potato. C. michiganensis subsp. michiganensis and C. michiganensis subsp. sepedonicus are the causative agents of bacterial wilt and canker of tomato and potato, respectively. $R$. solanacearum is the pathogen that causes also bacterial wilt of both plant species. The most common and threatening fungal tomato disease, which causes up to $\$ 6$ billion in crop damage each year [Nowicki et al. 2011] is the late blight caused by Phytophthora infestans (Mont.) de Bary [Blancard et al. 2012]. It can also seriously damage potatoes. In Ukraine, these bacterial and fungal pathogens are the most hazardous for tomato [Kolomiets et al. 2017; 2019a; 2019b] and potato [Gordienko \& Zaharchuk, 2017; Boroday et al., 2018] production.

The problem of developing new tomato and potato varieties resistant to a wide range of phytopathogens is of great interest. For example, in Ukraine during the years 2010-2014, more than ten thousand tomato cultivars were analyzed for their resistance to fungal pathogens, and more than $75.4 \%$ of the varieties were highly sensitive to fungal diseases [Shotyk et al. 2014]. In order to increase the systemic resistance to biotic stress in different plant species, different genetic engineering approaches are used. One of them is a transfer of lactoferrin gene into plant genomes and its efficient expression in transgenic plant lines [see review Yemets et al. 2014].

Lactoferrin is an iron-binding protein of the transferrin family, which is present in large quantities in milk and secretory fluids of mammals. Lactoferrin is a component of the human innate nonspecific immune system since it has antiinflammatory, anti-cancer, anti-viral, bactericidal, fungistatic, etc. activities [Yemets et al., 2014]. Therefore, the transduction and integration of this gene into the genome of commercially valuable plant varieties can increase its resistance to phytopathogens of bacterial, viral and fungal origin [Lakshman et al. 2013; Yemets et al. 2014]. In previous studies, antibacterial effects in transgenic tobacco [Sohrabi et al. 2014; Zhang 1998], rice [Takase et al. 2005], tomato [Lee et al. 2002], antiviral activities in potato [Taha et al. 2015], and fungistatic action in wheat [Han et al. 2012] etc. of lactoferrin gene expression have been found.

We have developed also the methods of the Agrobacterium-mediated transformation of different tomato (Lycopersicon esculentum Mill.) and potato (Solanum tuberosum) varieties with the hu-

\footnotetext{
${ }^{\circ}$ YEMETS A.
} 
man lactoferrin gene $(h L f)$ and the expression of recombinant human lactoferrin in transgenic tomato and potato plants. Transformation was carried out with the use of supervirulent $A$. tumefaciens strain EHA105 carrying the binary vector pBin35LF. It contained human lactoferrin cDNA under the control of the constitutive Cauliflower Mosaic Virus (CaMV) 35S promoter and of the octopine synthase gene terminator (OcsT), and npt II selectable marker gene encoding neomycin phosphotransferase II under control of the nopaline synthase promoter and CaMV 35S terminator [Buziashvili et al., 2020a, 2020b]. For genetic transformation of tomato with the $h L f$ gene, the Money Maker cultivar was used as a model cultivar for physiological and transformational studies of tomato with easy and well-adapted transformation methods. Another cultivar of our choice was widely used in the agricultural sector Ukrainian tomato cultivar Lahidny [Buziashvili et al., 2020b]. For potato transformation four potato cultivars: Vernisage, Levada, Svitanok and Zarevo, kindly provided by Institute of Potato, National Academy of Agrarian Sciences of Ukraine were used [Buziashvili et al., 2020a].

In order to confirm the integration of the gene of interest $(h L f)$ into the plant genome (after selection of tomato and potato lines on media containing selectable agent kanamycin) PCR analysis of kanamycin-resistant plants was performed using primers specific to $h L f$ gene. The products of PCR amplification corresponded to the expected PCR product of $731 \mathrm{bp}$. No amplification was found in the DNA controls of non-transformed plants. To confirm the expression of $h L f$ in transgenic tomato and potato lines, a Western blot was performed using the primary antibody against lactoferrin. The protein detected had a molecular mass of approximately $80 \mathrm{kDa}$, similar to that of the full-length native human lactoferrin. Samples of non-transformed plants (control) did not react with the antibody against human lactoferrin [Buziashvili et al., 2020a, 2020b].

The resistance to phytopathogenic bacteria $R$. solanacearum and $C$. michiganensis was investigated for transgenic plants with the use of disk diffusion assay. The zones of growth inhibition were detected around the disks loaded with the samples isolated from transgenic plants. A significant correlation was found between the inhibitory effect on bacterial growth and the concentration of lactoferrin in the samples. The in vitro study of transgenic plants' sensitivity (aseptic plants) to P. infestans was performed using the assay on resistance to late blight. For this analysis transgenic and control were infected in vitro with conidia of P. infestans. Dynamics of the development of symptoms were observed in 1-8 days of post-inoculation, indicating signs such as brown necrotic spots, wilting and the presence of viable mycelium [Buziashvili et al., 2020a, 2020b].

It has been shown that the obtained transgenic plants have the increased resistance to bacterial phytopathogens such as $R$. solanacearum, $C$. michiganensis subsp. michiganensis, C. michiganensis subsp. sepedonicus, and to the fungal pathogen $P$. infestans. The data obtained suggest that the transfer of the human lactoferrin gene to plants could be an alternative strategy to increase the resistance of commercially valuable plants against a wide range of bacterial and fungal phytopathogens and improve crop quality.

\section{References}

1. Blancard D., Laterrot H., Marchoux G., Candresse T. Tomato Diseases Identification, Biology and Control: A Color Handbook. Manson Publ. Ltd, London. 2nd ed., 2012.

2. Boroday V.V., Parfeniuk A.I. Spreading and development of the main potato (Solanum tuberosum L.) diseases in Ukraine, Agroecol. J. 2018. Vol. 4, P. 82-87. doi 10.33730/2077-4893.4.2018.161774. (in Ukr.)

3. Buziashvili A., Cherednichenko L., Kropyvko S., Blume Y., Yemets A. Obtaining of transgenic potato plants expressing human lactoferrin gene and analysis of their resistance to phytopathogens. Cytol. Genet. 2020a. Vol. 54, No. 3. P. 3-15

4. Buziashvili A., Cherednichenko L., Kropyvko S., Yemets A. Transgenic tomato lines expressing human lactoferrin show increased resistance to bacterial and fungal pathogens. Biocatal. Agricul. Biotech. 2020b, accepted for publication.

5. Fiers M., Edel-Hermann V., Chatot C., Alabouvette C., Steinberg Ch. Potato soil-borne diseases. A review. Agron. Sustain. Dev. 2012. No. 32. P. 93-132. https://doi.org/10.1007/s13593-011-0035-z.

6. Gordienko V.V., Zaharchuk N.A. Creation of initial breeding material of potato with complex resistance to fusarium dry rot and tuber late blight. Plant Varieties Stud. Protection. 2017. Vol. 13, No. 3. P. 239-244. doi: 10.21498/25181017.13.3.2017.110705. (in Ukr)

7. Han J., Lakshman D.K., Galvez L.C., Mitra S., Baenziger P.S., Mitra A. Transgenic expression of lactoferrin imparts enhanced resistance to head blight of wheat caused by Fusarium graminearum. Plant Biol. 2012. Vol. 12. P. 33-42. https://doi.org/10.1186/1471-2229-12-33.

8. Kolomiiets Y., Grygoryuk I., Likhanov A., Butsenko L., Blume Y. Induction of bacterial canker resistance in tomato plants using plant growth promoting. Rhizobacteria. Open Agric. J. 2019b. Vol. $13 . \quad$ P. $215-222$. https://doi.org/10.2174/1874331501913010215. 
9. Kolomiiets Y.V., Grygoryuk I.P., Butsenko L.M. Bacterial diseases of tomato plants in terms of open and covered growing of Ukraine. Ann. Agri. Sci. 2017. Vol. 15. P. 213-216. https://doi.org/10.1016/j.aasci. 2017.05.010.

10. Kolomiiets Y.V., Grygoryuk I.P., Butsenko L.M., Kalinichenko A.V. Biotechnological control methods against phytopathogenic bacteria in tomatoes. Appl. Ecol. Env. Res. 2019a. Vol. 17. P. 3215-3230. https://doi.org/10.15666/aeer/1702_32153230.

11. Lakshman D.K., Natarajan S., Mandal S., Mitra A. Lactoferrin derived resistance against plant pathogens in transgenic plants. J. Agric. Food Chem. 2013. Vol. 61. P. 11730-11735. https://doi.org/10.1021/ jf400756t.

12. Lee T.J., Coyne P.P., Clemente T.E., Mitra A. Partial resistance to bacterial wilt in transgenic tomato plants expressing antibacterial lactoferrin gene. J. Am. Soc. Hort. Sci. 2002. Vol. 127. P. 158-168. https://doi.org/ 10.21273/JASHS.127.2.158.

13. Nowicki M., Foolad M.R., Nowakowska M., Kozik E.U. Potato and tomato late blight caused by Phytophthora infestans: an overview of pathology and resistance breeding. Plant Dis. 2011. Vol. 96. P. 4-17. https://doi.org/10.1094/PDIS-05-11-0458.

14. Sohrabi S.M., Niazi A., Chahardooli M., Aram, F. Isolation and expression of antimicrobial camel lactoferrin $(c L f)$ gene in tobacco. Plant Omics J. 2014. Vol.7. P. 298-307.

15. Taha S.H., Mokbel S.A., Abdel-Hamid M., Hamed A.H. Antiviral activity of lactoferrin against potato virus $\mathrm{x}$ in vitro and in vivo. Int. J. Dairy Sci. 2015. Vol. 10. P. 86-94. https://doi.org/10.3923/ijds.2015.86.94.

16. Takase K., Hagiwara K., Onodera H., Nishizawa Y., Ugaki M., Omura T., Numata S., Akutsu K., Kumura H., Shimazaki K. Constitutive expression of human lactoferrin and its N-lobe in rice plants to confer disease resistance. Biochem. Cell Biol. 2005. Vol. 83. P. 239-249. https://doi.org/10.1139/o05-022.

17. Yemets A.I., Tanasienko I.V., Krasylenko Y.A., Blume Y.B. Plant-based biopharming of recombinant human lactoferrin. Cell Biol. Int. 2014. Vol. 38. P. 989-1002. https://doi.org/10.1002/cbin.10304.

18. Zhang Z., Coyne D.P., Vidaver A.K., Mitra A., Expression of human lactoferrin cDNA confers resistance to Ralstonia solanacearum in transgenic tobacco plants. Phytopathology. 1998. Vol. 88. P. 730-734. https://doi.org/10.1094/PHYTO. 